\title{
PENGEMBANGAN KEMAMPUAN PENALARAN MATEMATIS SISWA MELALUI PEMBELAJARAN BERBASIS MULTI REPRESENTASI DI SMP
}

\author{
Isnurani \\ Program Studi Matematika, FMIPA - UNPAM \\ isnurani99@gmail.com
}

\begin{abstract}
The purpose of this research is to find out the development of student's mathematical reasoning in associated to rectangular circumference material after giving them the multi representation based learning in Class VII Junior High School. The method used is experimental using Pretest-Posttest Control Group Design. The sample in this research is the students of Class VII SMP totaled 2 Class which are Class VII B as 1st experiment class and the students of Class VII C as 2nd experiment class. The result are : (1) there are the differences of student's mathematical reasoning based on Pretest and Posttest after giving them the multi representation based learning through enactive, iconic, and symbolic (1st experiment) and through symbolic, iconic, and enactive (2nd experiement); and (2) there is no differences of student's mathematical reasoning based on postest which been taught to them through the multi representation based learning by enactive, iconic, and symbolic (1st experiment) and even by symbolic, iconic, and enactive (2nd experiement).
\end{abstract}

Keywords: Mathematical Reasoning, Multi Representation

\begin{abstract}
ABSTRAK
Tujuan penelitian ini adalah untuk mengetahui pengembangan kemampuan penalaran matematis siswa terkait dengan materi keliling persegi panjang setelah mereka diberikan pembelajaran berbasis multi representasi di kelas VII SMP. Metode penelitian yang digunakan adalah eksperimen dengan menggunakan rancangan PretestPostest Control Group Design. Sampel dalam penelitian ini adalah siswa kelas VII SMP sebanyak dua kelas yaitu siswa kelas VII B sebagai sebagai kelas eksperimen 1 dan siswa kelas VII C sebagai kelas eksperimen 2. Hasil penelitian yang diperoleh adalah: (1) terdapat perbedaan kemampuan penalaran matematis siwa berdasarkan pretes dan postes setelah diajarkan melalui pembelajaran berbasis multi representasi melalui sajian enaktif, ikonik, dan simbolik (eksperimen 1) maupun sajian simbolik, ikonik, dan enaktif (eksperimen 2); dan (2) tidak terdapat perbedaan kemampuan penalaran matematis siswa berdasarkan postes antara mereka yang diajarkan melalui pembelajaran berbasis multi representasi melalui sajian enaktif, ikonik, dan simbolik (eksperimen 1) maupun melalui sajian simbolik, ikonik, dan enaktif (eksperimen 2).
\end{abstract}

Kata kunci: Penalaran Matematis, Multi Representasi 


\section{PENDAHULUAN}

\subsection{Latar Belakang Masalah}

Tujuan pembelajaran matematika di setiap jenjang pendidikan tertera pada Standar Isi (Badan Nasional Standar Pendidikan, 2006) menyatakan bahwa agar siswa memiliki kemampuan menggunakan penalaran. Kemampuan penalaran yang dimaksud adalah kesanggupan siswa berpikir logis menurut pengetahuan matematis yang dimilikinya melalui proses mengidentifikasi, mengajukan dugaan, menentukan, menghubungkan, dan mengkonfirmasi semua informasi yang dilakukan dalam pemecahan masalah. Oleh karena itu, sukar disangkal bahwa penalaran matematis mempunyai posisi yang strategis di dalam pembelajaran matematika.

Penalaran matematis merupakan sarana bagi guru untuk mengakomodasi pikiran siswa sehingga matematika yang dipelajarinya lebih bermakna dan logis bagi mereka. Penalaran matematis oleh The National Countil of Teaching of Mathematics (NCTM) yang menyebutkan bahwa satu di antara kemampuan matematis yang wajib dikuasai siswa (NCTM, 2000: 56). Bahkan penalaran matematis merupakan tujuan utama dari kurikulum matematika di seluruh dunia. Walaupun penalaran matematis merupakan tujuan utama dalam kurikulum, namun kenyataannya di lapangan menunjukkan bahwa pencapaian anak-anak Indonesia kurang mengembirakan dalam beberapa kali laporan yang dikeluarkan oleh Trends in International Mathematics and Science (TIMSS) dan Programe for International Student Assesment (PISA).

Bukti ini diperkuat lagi oleh hasil survey Indonesia Mathematics and Science Teacher Education Project-Japan International Corporation Agency (IMSTEP-JICA) dalam Herman (2007: 42), satu di antara penyebab rendahnya kualitas pemahaman dan penalaran matematis siswa dalam proses pembelajaran matematika yaitu pembelajaran berpusat pada guru, konsep matematika disampaikan secara informatif, dan siswa dilatih menyelesaikan banyak soal tanpa pemahaman yang mendalam. Akibatnya, kemampuan penalaran dan kompetensi strategis siswa tidak berkembang sebagaimana mestinya.

Di dalam mengembangkan kemampuan penalaran matematis siswa, ada beberapa standar yang telah digariskan oleh Badan Standar Nasional Pendidikan (BSNP) dan secara teoritis juga ditegaskan oleh NCTM, melalui "the teaching principle" dua di antaranya: (1) Anak-anak mengkontruksi sendiri pengetahuan dan pemahaman mereka; dan (2) Pembelajaran aktif mencari dan menemukan sendiri ide matematika dengan 
pendekatan sains (NCTM, 2000; BNSP, 2006; Kunandar, 2013: 24). Kemampuan ini termasuk ke dalam komponen proses bermatematika yang lazimnya dinamakan daya matematis (NCTM, 2000; BNSP, 2006; Sugiatno, 2013: 2). Sedangkan kemampuan yang akan dimunculkan melalui komponen proses bermatematika dalam penelitian ini adalah penalaran matematis.

Namun pada kenyataannya pembelajaran yang ada terkesan kurang memperhatikan the teaching principle yang mengakibatkan siswa sulit mengkontruksi sendiri pengetahuan dan pemahamannya untuk mengaplikasikan rumus ke dalam pemecahan masalah sehingga penalaran matematis siswa tidak berkembang. Dalam proses pembelajaran matematika di kelas cenderung hanya menekankan algoritma pengerjaan untuk melatih siswa terampil menjawab soal matematika, dan pembelajaran matematika cenderung tersekat di kelas saja tanpa melibatkan kebutuhan matematika dalam kehidupan nyata sehingga pemahaman dan penalaran matematis siswa terabaikan.

Berdasarkan studi pendahuluan peneliti yang dilakukan di SMP Suster Pontianak diperoleh bahwa dalam proses pembelajaran: (1) dalam menyelesaikan soal-soal matematika guru tersebut tidak memberikan penjelasan mengenai makna-makna sajian soal yang diberikan, akibatnya dalam menjawab pertanyaan cenderung hanya secara prosedural tanpa mengerti makna dari apa yang ditulis atau diucapkan; (2) guru kurang memberikan kesempatan kepada siswa untuk menggali penalaran mereka karena pada dasarnya guru kurang memperhatikan apa yang diketahui siswa terhadap materi yang diberikan, akibatnya siswa menjawab pertanyaan tanpa mengikutsertakan proses bernalar sehingga jawaban yang mereka berikan terkadang tidak masuk akal; dan (3) masih banyak siswa yang mengalami kesulitan dalam sub bab pokok bahasan persegi panjang, terutama dalam memahami dan menggunakan rumus.

Hal tersebut diperkuat dari penemuan National Assesment of Educational Progress (NAEP) dalam Van De Walle (2006: 128) menyebutkan bahwa kesalahan yang umum adalah luas dan keliling (jarak sekeliling daerah) terus menjadi sumber kebingungan siswa. Mungkin itu disebabkan keduanya melibatkan daerah yang sama akan diukur atau karena siswa diajarkan rumus-rumus untuk kedua konsep tersebut dan cenderung tertukar. Kinerja seperti ini seringkali terjadi akibat penekanan berlebihan pada rumus-rumus dengan sedikit atau tanpa latar belakang konseptual. Guru hanya 
berfokus mengejar materi agar materi tersebut dapat terselesaikan sesuai dengan kurikulum yang ditetapkan, sementara itu pada kurikulum sekarang kegiatan bernalar merupakan kegiatan yang harus diperhatikan oleh para guru.

Berdasarkan uraian yang telah dikemukakan sebelumnya, perlu kiranya perhatian pada bentuk evaluasi matematika yang menumbuh kembangkan penalaran matematis. Oleh karena itu penalaran matematis dalam matematika memiliki peran penting dalam proses berpikir seseorang. Bila kemampuan penalaran matematis tidak dikembangkan pada siswa, maka bagi siswa matematika hanya akan menjadi materi yang mengikuti serangkaian prosedural dan meniru contoh-contoh tanpa mengetahui maknanya. Mengingat peran penalaran matematis yang fundamental, sebaiknya dalam proses pembelajaran guru mendorong siswa secara terus menerus untuk menumbuhkembangkan penalaran matematis dan diperlukannya sarana untuk menjembatani proses penalaran matematis melalui berbagai bentuk representasi agar siswa mampu menarik kesimpulan yang logis menurut pengetahuan matematis yang dimilikinya.

Sebagai contoh bentuk proses penalaran matematis, misalnya diawali dengan memanipulasi benda konkrit seperti model persegi panjang, permukaan meja, atau buku gambar, sebagai bentuk representasi enaktif dari persegi panjang. Kemudian aktivitas tersebut diingat dan menghasilkan serta memperkaya gambar-gambar atau representasi ikonik. Dengan mengembangkan dan mengajukan berbagai dugaan untuk menentukan dan menyelesaikan suatu masalah sebagai perwujudan representasi simbolik (Hudiono, 2007: 18-19). Dalam hal ini tampak pada saat proses pembelajaran berlangsung yaitu saat siswa mengasosiasi dua objek atau lebih (objek yang dimaksud adalah keliling persegi panjang) sebagai bentuk proses bernalar siswa.

Dari hasil proses bernalar tersebut terlihat bahwa penyelesaian terhadap permasalahan yang diberikan menunjukkan adanya sikap yang lebih berhati-hati dan terstruktur. Aktivitas ini menunjukkan adanya bagaimana proses penalaran itu terjadi sehingga siswa mampu menarik kesimpulan logis dari apa yang telah mereka pelajari. Berkaitan dengan peran representasi dalam upaya mengembangkan dan mengoptimalkan kemampuan penalaran matematis siswa, sangat tepat jika dalam Principles and Standards for School Mathematics (NCTM, 2000; Hudiono, 2007: 8) mencantumkan representasi sebagai satu di antara standar proses belajar mengajar matematika cukup beralasan karena untuk berpikir matematika dan mengkomunikasikan 
ide-ide matematika, seseorang perlu merepresentasikannya dalam berbagai cara. Selain itu, tidak dapat dipungkiri bahwa obyek dalam matematika itu semuanya abstrak dan untuk mempelajari dan memahami ide-ide abstrak itu memerlukan representasi (Hudiono, 2007: 9).

Hiebert dan Carpenter (Hudoyo, 2002) mengemukakan bahwa pada dasarnya representasi dapat dinyatakan sebagai internal dan eksternal. Berpikir tentang ide matematika yang kemudian dikomunikasikan memerlukan representasi eksternal yang wujudnya antara lain: verbal, gambar dan benda konkrit. Representasi internal dari seseorang sulit untuk diamati secara langsung karena merupakan aktivitas mental dari seseorang dalam pikirannya (minds-on). Tetapi representasi internal seseorang itu dapat disimpulkan atau diduga berdasarkan representasi eksternalnya dalam berbagai kondisi, misalnya dari pengungkapannya melalui kata-kata (lisan), melalui tulisan berupa simbol, gambar, grafik, tabel ataupun melalui alat peraga (hands-on). Dengan kata lain terjadi hubungan timbal balik antara representasi internal dan eksternal dari seseorang ketika berhadapan dengan sesuatu masalah.

Selanjutnya, Bruner (Thornton, dkk, 1987: 85), menyatakan "knowledge can be represented in three forms: enactive, iconic, and symbolic. These three forms of knowledge serve as models for the storage and retrieval of useful information". Pengetahuan dapat direpresentasikan dalam tiga bentuk: enaktif, ikonik, dan simbolik. Ketiga bentuk pengetahuan berfungsi sebagai model penemuan kembali terkait informasi penting. Dalam pembelajaran matematika khususnya pada materi geometri akan selalu ada Figural (gambar) dan model (benda konkrit) yang dapat ditiru dalam pelaksanaan proses pembelajaran. Hal ini dapat membantu siswa untuk menyelesaikan masalah yang ada.

Oleh karena itu, multi representasi yang digunakan dalam penelitian ini mengacu pada tahapan teori Bruner (Thornton, 1987) yang diadaptasi dari Lesh and Doerr (2003), yaitu: enaktif, ikonik, dan simbolik (eksperimen 1) dan sebaliknya simbolik, ikonik, dan enaktif (eksperimen 2). Penggunaan representasi dengan menggunakan benda-benda konkrit dapat membantu proses bernalar siswa dalam materi keliling persegi panjang. Meskipun pembelajaran berbasis multi representasi bukan merupakan hal yang baru, namun kesadaran akan peranan penting multi representasi dalam pembelajaran matematika belum maksimal. Oleh karena itu, satu di antara pendekatan pembelajaran 
yang akan menggiring siswa melakukan proses bermatematika dengan mengkonstruksi sendiri pengetahuannya yang berhubungan dengan kehidupan sehari-hari, dan menemukan sendiri konsep melalui proses bernalar yang dilewati, maka diharapkan belajar siswa menjadi lebih bermakna. Maka jalan keluar yang ditawarkan dalam penelitian ini berjudul "Pengembangan Kemampuan Penalaran Matematis Siswa Melalui Pembelajaran Berbasis Multi Representasi".

\subsection{Rumusan Masalah}

Rumusan masalah dalam penelitian ini adalah:

1) Bagaimanakah pengetahuan awal siswa tentang kemampuan penalaran matematis dalam materi keliling persegi panjang antara siswa kelompok eksperimen-1 (enaktif, ikonik, dan simbolik), dan kelompok eksperimen-2 (simbolik, ikonik, dan enaktif) sebelum mengikuti pembelajaran berbasis multi representasi?

2) Apakah terdapat perbedaan kemampuan penalaran matematis siswa berdasarkan pretest dan postes antara mereka yang diajarkan melalui pembelajaran berbasis multi representasi baik kelompok eksperimen-1 (enaktif, ikonik, dan simbolik) dan kelompok eksperimen-2 (simbolik, ikonik, dan enaktif)?

3) Apakah terdapat perbedaan kemampuan penalaran matematis siswa berdasarkan postes antara mereka yang diajarkan melalui pembelajaran berbasis multi representasi kelompok eksperimen-1 (enaktif, ikonik, dan simbolik), dan kelompok eksperimen-2 (simbolik, ikonik, dan enaktif)?

\subsection{Tujuan Penelitian}

Tujuan dalam penelitian ini adalah untuk mendapatkan informasi tentang:

1) Mengkaji kemampuan awal siswa tentang kemampuan penalaran matematis dalam materi keliling persegi panjang antara kelompok eksperimen-1 (enaktif, ikonik, dan simbolik) dan kelompok eksperimen-2 (simbolik, ikonik, dan enaktif) sebelum mengikuti pembelajaran berbasis multi representasi.

2) Perbedaan kemampuan penalaran matematis siswa berdasarkan pretes dan postes antara mereka yang diajarkan melalui pembelajaran berbasis multi representasi baik kelompok eksperimen-1(enaktif, ikonik, dan simbolik) maupun kelompok eksperimen-2 (simbolik, ikonik, dan enaktif). 
3) Perbedaan kemampuan penalaran matematis siswa berdasarkan postes antara mereka yang diajarkan melalui pembelajaran berbasis multi representasi yang diberikan secara enaktif, ikonik, dan simbolik (eksperimen-1) dan sajian simbolik, ikonik, dan enaktif (eksperimen-2).

\subsection{Manfaat Penelitian}

Hasil penelitian ini memberikan manfaat dalam pembelajaran matematika di SMP khususnya dalam pengembangan kemampuan penalaran matematis siswa. Melalui pembelajaran berbasis multi representasi dapat meningkatkan kualitas dan keefektifan belajar. Selanjutnya, pembelajaran berbasis multi representasi dapat memberikan pengembangan kemampuan penalaran matematis siswa secara logis melalui aktifitas mengidentifikasi, mengajukan dugaan, menentukan, menghubungkan dan mengkomunikasikan untuk sampai pada pemahaman yang bermakna setelah mengikuti pelajaran.

\section{METODOLOGI PENELITIAN}

Metode penelitian yang digunakan adalah eksperimen. Menurut Sugiyono (2008; 107) metode penelitian eksperimen dapat diartikan sebagai metode penelitian yang digunakan untuk mencari pengaruh perlakuan tertentu terhadap yang lain dalam kondisi yang dikendalikan. Jenis penelitian yang digunakan adalah True Eksperimental Design menggunakan rancangan Pretest-Postest Control Group Design (Emzir, 2013: 98). Populasi dalam penelitian ini adalah seluruh siswa kelas VII SMP Suster Pontianak tahun pelajaran 2014/2015. Sedangkan jumlah sampel dalam penelitian ini ada dua kelompok siswa kelas VII SMP tersebut yang mempunyai kemampuan akademik setara.

Dari dua kelas tersebut selanjutnya dipilih secara acak untuk menentukan dua kelompok siswa yang akan diberikan pembelajaran berbasis multi representasi secara: (1) enaktif, ikonik, dan simbolik (eksperimen 1) dan; (2) simbolik, ikonik, dan enaktif (eksperimen 2). Dari kedua kelompok siswa ini yang memenuhi syarat sebagai sampel, yaitu siswa kelas VII B sebagai kelompok eksperimen 1 dan siswa kelas VII C sebagai kelompok eksperimen 2. 


\section{HASIL DAN PEMBAHASAN}

\subsection{Data Penelitian}

Dari hasil penelitian ini terdapat dua kelompok data yang diperoleh, yaitu: data pretes dan data postes (berupa skor 0-100) siswa yang berjumlah 60 siswa dari 2 kelas eksperimen. Secara umum untuk mendeskripsikan skor rerata yang sesuai dengan pretes dan postes pada kelompok eksperimen 1 (enaktif, ikonik, dan simbolik), dan eksperimen 2 (simbolik, ikonik, dan enaktif) masing-masing disajikan melalui Tabel berikut.

Tabel 1: Hasil Pretes dan Postes Kelompok Ekpserimen 1 dan Kelompok Eksperimen 2

\begin{tabular}{ccc}
\hline \multirow{2}{*}{ Jenis Data } & \multicolumn{2}{c}{ Kelompok Multi Representasi } \\
\cline { 2 - 3 } & Eksperimen-1 & Eksperimen-2 \\
\hline Pretes & 10.17 & 10.10 \\
\hline Postes & 11.97 & 11.80 \\
\hline
\end{tabular}

Untuk mengetahui kenaikan hasil belajar siswa antara kelompok eksperimen 1 dan kelompok eksperimen 2 berdasarkan rerata pretes dan postes dapat dilihat pada Diagram berikut.

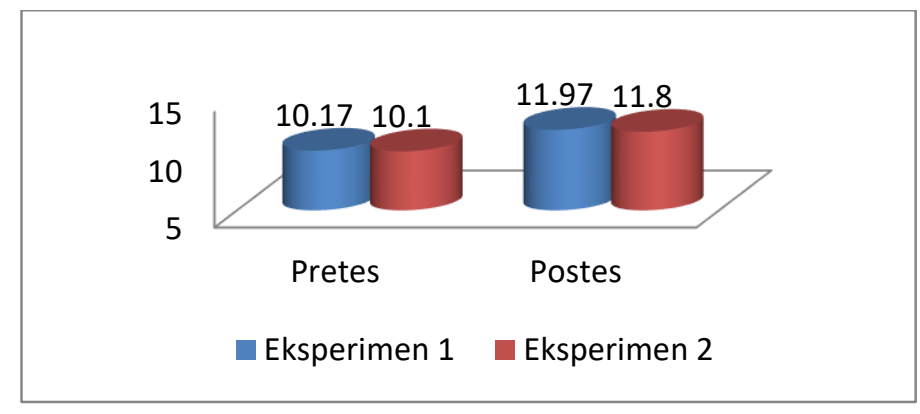

Diagram 1 Hasil Rerata Pretes dan Postes

\subsection{Pembahasan}

Sesuai dengan hasil uji hipotesis 1 bahwa secara signifikan menolak hipotesis nol. Artinya, pembelajaran matematika dalam materi keliling persegi panjang melalui pembelajaran berbasis multi representasi baik kelompok eksperimen 1 (enaktif, ikonik, dan simbolik) maupun kelompok eksperimen 2 (simbolik, ikonik, dan enaktif) mempengaruhi kemampuan penalaran matematis siswa. Oleh karena itu, terdapat perbedaan berdasarkan pretes dan postes antara kelompok eksperimen 1 dan kelompok eksperimen 2 .

Kenaikan rerata skor pretes dan postes baik kelompok eksperimen 1 maupun kelompok eksperimen 2 disebabkan oleh proses pembelajaran berikut: (1) untuk kelompok ekspermen 1 pembelajaran dimulai dari situasi dunia nyata (kehidupan sehari-hari) siswa yaitu melalui cerita kontekstual (konkret) $\rightarrow$ sajian gambar-gambar 
yang relevan (semikonkret) $\rightarrow$ simbol terkait materi keliling persegi panjang (abstrak); (2) untuk kelompok eksperimen 2 pembelajaran dimulai dari sajian gambar-gambar yang relevan dengan materi keliling persegi panjang $\rightarrow$ sajian cerita kontekstual $\rightarrow$ simbol. Hasil ini ternyata terkonfirmasi oleh beberapa penelitian lain mengenai pengaruh sajian multi representasi terhadap kemampuan penalaran matematis siswa (Horison, Suydam dan Higgins, 2010: 1; Sugiatno dan Rif'at, 2009; dan Alhadad, 2010).

Teruji secara empirik bahwa kedua sajian pembelajaran berbasis multi representasi dapat diserap mereka dan kemampuan penalaran matematis siswa sebelum diberikan pembelajaran berbasis multi representasi kondisinya tidak berbeda secara signifikan atau sampel yang digunakan dalam kelompok penelitian berasal dari populasi yang sama. Hal ini didasarkan pada rerata hasil postes yaitu 11.97 (eksperimen 1) dan 11.80 (eksperimen 2). Selanjutnya jika dilihat berdasarkan hasil jawaban siswa dalam menjawab soal bahwa siswa dapat menyelesaikan soal dengan baik. Hal ini terlihat antara siswa kelas eksperimen 1 maupun eksperimen 2, pada kelompok atas kelompok eksperimen 1 dengan rerata 18.875 terdapat 4 orang siswa yang dapat memenuhi ketujuh aspek penalaran matematis (rubrik penskoran) dengan mendapatkan skor 20, sedangkan kelompok ekperimen 2 dengan rerata 18.75 terdapat 3 orang siswa yang dapat memenuhi ketujuh aspek penalaran matematis dengan mendapatkan skor 20.

Mencermati Diagram 1 mengindikasikan bahwa kenaikan hasil belajar dari rerata pretes ke rerata postes yang diperoleh dan berdasarkan hasil observasi aktivitas siswa selama proses pembelajaran, dikarenakan beberapa hal antara lain: (1) proses pembelajaran berbasis multi representasi yang digunakan berbeda dari proses pembelajaran sebelumnya (konvensional); (2) kegiatan proses pembelajaran secara kooperatif (diskusi) melibatkan siswa secara aktif dalam melakukan aktivitas matematis; (3) sumber belajar dan media pembelajaran yang digunakan sangat dekat dengan kehidupan siswa; (4) siswa melakukan proses belajar tidak hanya dengan guru, tetapi dengan teman sebaya, orang dewasa, dan lingkungan; dan (5) siswa terlibat langsung dalam melakukan diskusi dengan rekannya maupun dengan guru mengenai permasalahan terkait materi keliling persegi panjang, sehingga siswa dapat mengkontruksi dan mengevaluasi argumen-argumen rekannya. Serta dapat melakukan generalisasi saat penarikan kesimpulan. 
Hal tersebut sejalan dengan teori Vygotsky (Kozulin, 2003) yang menekankan pada hakikat sosiokultural dari pembelajaran. Dua implikasi utama dari teori Vygotsky dalam pembelajaran. Pertama, dikehendakinya susunan kelas berbentuk pembelajaran kooperatif antar siswa, sehingga siswa dapat berinteraksi disekitar tugas-tugas yang sulit dan saling memunculkan strategi pemecahan masalah yang efektif di dalam masingmasing zone of proximal development mereka. Pembelajaran kooperatif ini terwujud melalui kegiatan pembelajaran secara berkelompok yang telah dilaksanakan yang terdiri dari 5 siswa. Kedua, dalam pengajaran menekankan pemberian scaffolding sehingga siswa semakin lama semakin bertanggung jawab terhadap pembelajarannya sendiri. Misalnya, dalam pengajaran timbal balik, guru memimpin kelompok-kelompok kecil siswa untuk mengajukan pertanyaan terkait keliling persegi panjang yang telah mereka pelajari dan secara bertahap mengalihkan tanggungjawab untuk memimpin diskusi tersebut kepada siswa lain.

Menurut Vygotsky dalam Kozulin (2003) menyatakan bahwa pentingnya interaksi sosial dalam perkembangan kognitif. Perkembangan kognitif bergantung pada seberapa jauh siswa aktif memanipulasi dan berinteraksi aktif dengan lingkungannya. Hal ini mengindikasikan bahwa lingkungan di mana siswa belajar sangat menentukan proses perkembangan kognitifnya. Perkembangan kognitif yang dimaksud adalah kemampuan penalaran matematis siswa. Vygotsky dalam Kozulin (2003) mengemukakan bahwa interaksi-interaksi seseorang dengan lingkungan dapat membantu pembelajaran. Pengalaman-pengalaman yang dibawa seseorang (siswa) ke sebuah situasi pembelajaran dapat sangat mempengaruhi hasil belajar.

Ketika siswa bersama teman-teman sebayanya bekerja sama mengerjakan tugastugas, interaksi-interaksi sosial yang sama-sama mereka jalani dapat berperan sebagai fungsi pengajaran. Melalui komunikasi dan tindakan, orang-orang yang berada dalam lingkungan anak mengajarkan alat-alat kepada anak (misalnya, bahasa simbol, tanda) yang mereka butuhkan untuk memperoleh kompetensi (Schunk, 2012: 581). Interaksi sosial dengan guru, orang tua dan teman sebaya yang lebih berpengalaman memberikan kontribusi yang signifikan bagi perkembangan intelektual dan kemampuan penalaran matematis siswa.

Namun, hasil uji hipotesis 2 menunjukkan bahwa secara signifikan menerima hipotesis nol. Artinya, tidak terdapat perbedaan yang signifikan terhadap kemampuan 
penalaran matematis siswa berdasarkan postes antara mereka yang diajarkan menggunakan kelompok eksperimen 1 (enaktif, ikonik, dan simbolik) dan kelompok eksperimen 2 (simbolik, ikonik, dan enaktif). Tidak terdapatnya perbedaan ini disebabkan oleh beberapa hal, di antaranya: pembelajaran dimulai dari simbol terkait materi keliling persegi panjang (abstrak) $\rightarrow$ sajian model (semikonkret) yang relevan $\rightarrow$ cerita kontekstual (konkret). Siswa hafal rumus tetapi belum dapat mengaplikasikannya dan siswa tidak memiliki pemahaman yang baik terhadap rumus (simbol), karena siswa kurang memahami apa yang dimaksud dengan keliling persegi panjang maupun rumus atau makna simbol yang digunakan. Hasil ini diperkuat dengan pendapat Van De Walle, Karp, dan Bay-Williams (2010; 257), 'they do not have a strong understanding of the symbols' yang artinya kurang lebih diduga siswa tersebut kurang memiliki pemahaman yang kuat dari simbol-simbol itu.

Sugiatno dan Rif'at (2009: 12-13) menyatakan bahwa simbol-simbol matematika bersifat tiruan yang hanya mempunyai arti setelah sebuah makna diberikan kepadanya. Tanpa arti dari simbol-simbol tersebut, maka matematika hanya merupakan ungkapan-ungkapan atau rumus-rumus yang mati. Oleh karena itu, simbol-simbol matematis (terintegrasi pada pesan) yang dikomunikasikan matematikawan "secara langsung" sebagai komunikator, jika tidak diberi sebuah makna, maka akan sukar diterima oleh seseorang penerima pesan (siswa) terutama yang baru belajar matematika.

Berdasarkan Diagram 1 jika dicermati nilai rerata nilai postes kelompok eksperimen 1 hanya sedikit lebih tinggi dibandingkan dengan kelompok eksperimen 2. Hal ini disebabkan oleh beberapa hal, antara lain: (1) Kedua sajian tersebut mengenai materi keliling persegi panjang sama-sama terjangkau oleh pikiran siswa; (2) Siswa belum terbiasa dan masih banyak mengalami kesulitan dalam belajar yang berawal dari sajian simbolik, ikonik, dan enaktif; dan (3) Siswa hanya mampu menunjukkan lima atau empat aspek penalaran yaitu: siswa dapat mengidentifikasi masalah dengan siswa dapat menunjukkan apa yang diketahui dan apa yang ditanyakan; siswa dapat menentukan rumus dalam menyelesaikan masalah yang diberikan; siswa dapat melakukan perhitungan dengan benar; siswa tidak mengkonfirmasi hasil jawaban terkait masalah yang diberikan; dan jawaban akhir benar, namun terkadang jawaban akhir salah. Hal ini didasarkan pada rerata hasil postes pada kelompok tengah yaitu kelompok eksperimen 1 dengan rerata 12.538, terdapat 2 orang siswa yang mampu mendapatkan 
skor 16, sedangkan kelompok ekperimen 2 dengan rerata 12.154 dan terdapat 1 orang siswa yang mendapatkan skor 15. Pada kelompok tengah kesulitan yang dihadapi adalah siswa lebih sering tidak dapat mengajukan dugaan dan siswa tidak dapat menghubungkan keliling persegi panjang melalui tahapan simbolik, ikonik, dan enaktif. Hal ini disebabkan karena siswa belum terbiasa menghubungkan dua bentuk representasi atau lebih untuk mewakili suatu ide (konsep) matematis yang sama. Hasil temuan tersebut diperkuat dengan penelitian terdahulu oleh (Alhadi, Sugiatno, Suratman, 2013)

Ditemukan juga ada beberapa siswa hanya dapat memenuhi satu aspek penalaran matematis yaitu siswa hanya dapat melakukan perhitungan dengan benar namun jawaban akhir salah maupun sebaliknya. Siswa dengan tingkat kemampuan bawah lebih banyak kesalahan dan tidak dapat menyelesaikan soal postes yang diberikan, hal ini tergambar pada lembar jawaban soal no 1, 2, 4 dan 5. Siswa tidak dapat mengidentifikasi, siswa tidak dapat mengajukan dugaan, siswa tidak dapat menentukan, siswa tidak dapat menghubungkan; siswa tidak dapat mengkonfirmasi jawaban dan terkadang jawaban akhir benar. Siswa lebih sering hanya dapat melakukan perhitungan tetapi perhitungan yang dilakukan tidak runtut.

Namun terkadang siswa dapat mengidentifikasi masalah yang ada, misalnya siswa hanya dapat menentukan berapa panjang dan berapa lebarnya dari keliling persegi panjang tetapi siswa tidak dapat menyelesaikan masalah tersebut. Terdapat beberapa siswa tidak dapat melakukan proses ketidakseimbangan antara informasi baru dengan struktur kognitif yang ada pada dirinya yang meng-akibatkan tidak runtutnya siswa melakukan perhitungan dalam proses penye-lesaian masalah hingga penarikan kesimpulan. Diduga juga, siswa kurang mampu menghubungkan atau mengkoneksikan dari representasi simbol, ikonik, dan enaktif hal ini tergambar pada jawaban soal postes no 4, ditemukan banyak siswa yang kurang mampu menyelesaikannya. Temuan tersebut diperkuat dengan penelitian terdahulu oleh Sriraman dan English (2010); Kurniadi (2013) dan Alhadi, Sugiatno, Suratman (2013).

Hal tersebut sejalan dengan pendapat Piaget (dalam Sugiatno dan Rif'at, 2009: 7) bahwa disequilibrium merupakan pemicu terjadinya belajar, karena proses akomodasi tidak akan terjadi tanpa adanya proses disequilibrium (ketidakseimbangan). Piaget (dalam Oakley, 2005; Sugiatno dan Rif' at, 2009: 16) menyatakan bahwa perkembangan 
manusia tidak dapat 'diberi informasi' yang kemudian secara tiba-tiba dapat memahami dan menggunakannya, tetapi manusia (siswa) harus mengkontruksi pengetahuan mereka sendiri. Kesulitan siswa dalam proses penyeimbangan antara informasi baru dengan struktur kognitif yang ada disebabkan oleh pembelajaran yang cenderung menekankan pada hafalan, cen-derung tanpa melalui proses konstruksi pengetahuan oleh siswa sendiri sehingga siswa sulit mengungkapkan kemampuan penalaran matematis siswa.

Hal tersebut sejalan dengan pendapat Alhadi, Sugiatno dan Suratman (2013: 2) menyatakan representasi adalah cara mengekspresikan ide-ide mate-matis melalui simbol, gambar, diagram, tabel, grafik, manipulatif ataupun benda-benda konkret. Dalam NCTM (Alhadi, Sugiatno, dan Suratman, 2013: 2) tertuang bahwa 'representations should be treated as essential elements in supporting students understanding of mathematical concepts and relationships' yang artinya kurang lebih representasi harus diperlakukan sebagai komponen yang utama dalam mendukung pemahaman siswa dari berbagai konsep dan hubungan matematis.

Oleh karena itu, dalam penelitian ini menggunakan pembelajaran berbasis multi representasi yang mengacu pada teori Bruner (Thorton, dkk, 1987) dan diadaptasi dari Lesh and Doerr (2003) yaitu: (1) pembelajaran berbasis multi representasi melalui sajian enaktif, ikonik, dan simbolik (eksperimen 1); dan (2) pembelajaran berbasis multi representasi melalui sajian simbolik, ikonik, dan enaktif, (eksperimen 2). Sedangkan sajian enaktif ke ikonik tergambar pada soal no. 1; (2) ikonik ke enaktif tergambar pada soal no. 2; (3) enaktif ke simbolik tergambar pada soal no. 3; dan (4) ikonik, simbolik dan enaktif tergambar pada soal no. 4; maupun sebaliknya enaktif, ikonik, dan simbolik, tergambar pada soal no. 5 .

\section{SIMPULAN DAN SARAN}

\subsection{Kesimpulan}

Berdasarkan kesesuaian antara teori dan aplikasi yang terjadi di lapangan selama proses penelitian inilah menjadi dasar bahwa pengembangan kemampuan penalaran matematis siswa mengalami peningkatan. Bentuk pengembangan kemampuan penalaran matematis siswa tersebut terlihat dari tes hasil belajar siswa yang sebagian besar mengalami ketuntasan individual. Dengan mengacu pada nilai pre-test dan post-test, terlihat bahwa rerata kelompok eksperimen 1 lebih tinggi dibanding kelompok eksperimen 2. Perhitungan rerata dan uji paired samples test dalam analisis ini untuk 
menggambarkan bahwa pengembangan penalaran matematis siswa memang disebabkan oleh perlakuan selama proses penelitian dan bukan perlakuan yang sebelumnya. Oleh karena teori oleh Bruner (Thorton, 1987) dan Lesh and Doerr (2003: 449) dapat digunakan dalam pembelajaran matematika.

\subsection{Saran}

Pembelajaran melalui sajian enaktif, ikonik, dan simbolik (eskperimen 1) dan sajian simbolik, ikonik, dan enaktif (eksperimen 2) dimungkinkan dapat diterapkan pada sekolah yang menerapkan kurikulum 2013. Hal ini sesuai dengan tinjauan bahwa dalam pembelajaran K-13, satu diantara komponen kompetensi dasar adalah penalaran matematis. Sedangkan pendekatan pembelajarannya, menekankan pada pemahaman dan penalaran matematis yang dibangun siswa dengan bimbingan guru, dan bila mungkin setiap penanaman konsep matematika dimulai dengan pengenalan masalah konstektual. Penelitian ini dapat dilanjutkan dan lebih menarik, selain meningkatkan keterlibatan siswa dalam memanipulasi berbagai representasi, dan sebaiknya instrumen yang digunakan didukung oleh wawancara mendalam untuk mengungkap semua aspek penalaran matematis.

\section{DAFTAR PUSTAKA}

Alhadad, S. F. (2010). Meningkatkan Kemampuan Representasi Multipel Matematis, Pemecahan Masalah, dan Self Esteem Siswa SMP Melalui Pembelajaran dengan Pendekatan Open Ended. Bandung: Universitas Pendidikan Indonesia.

Alhadi. S, Sugiatno, Suratman. D. (2013). Pemahaman Konseptual Siswa Dikaji dari Representasi Matematis dalam Materi Fungsi Kuadrat di SMA. Pontianak: Jurnal pendidikan matematika.

Badan Standar Nasional Pendidikan. (2006). Standar Kompetensi dan Kompetensi Dasar SMP/MTs. Jakarta: BSNP.

Emzir. (2013). Metode Penelitian Pendidikan Kuantitatif \& Kualitatif. Jakarta: PT Raja Grafindo Persada.

Kozulin. A. et al. (2003). Vygotsky Education Theory in Cultural Context. New York: Cambridge University Press.

Kurniadi. A. (2013). Koherensi Sajian Antar Komponen Kecakapan Matematis Materi Trigonometri Dalam Buku Teks Matematika SMA. Pontianak: Universitas Tanjungpura. Skripsi. 
Herman. T. (2007). Prosiding Seminar Nasional Matematika: Pembelajaran Matematika Berbasis Masalah Untuk Meningkatkan Kemampuan Penalaran Matematika SMP. Bandung: Jurnal Nasional Pendidikan Matematika.

Hudiono. B. (2005). Peran Pembelajaran Diskursus Multi Representasi Terhadap Pengembangan Kemampuan Matematika dan Daya Matematis Siswa SLTP. Bandung: Universitas Pendidikan Indonesia. Disertasi.

Hudoyo. H. (2002). Representasi Belajar Berbasis Masalah. Jurnal Matematika atau Pembelajarannya. ISSN: 085-7792. Tahun viii, edisi khusus.

National Countil of Teachers of Mathematics. (2000). Principle and Standards for Schools Mathematics. Resto, VA.

Lesh. R. and Doerr. M. H. (2003). Beyond Contructivesm. Models and Modeling Perspectives on Mathematicd Problem Solving, Learning, and Teaching. London: Lawrence Erbaum Associates, Publishers.

Schunk, D. H. (2012). Learning theories an educational perspective. Boston: Person.

Sugiatno, Rif'at, M. (2009). Mengembangkan Kemampuan Komunikasi Matematis Mahasiswa Calon Guru Melalui Perkuliahan Matematika Dengan Menggunakan Model Pembelajaran Transactional Reading Strategy. Pontianak: Universitas Tanjungpura. Makalah.

(2013). Pengembangan Soal-Soal Open-Ended Berbasis Daya dan Kecakapan Matematis di SMP. Pontianak: Universitas Tanjungpura. Makalah.

Sugiyono. (2008). Metode Penelitian Pendidikan (Pendekatan Kualitatif, Kuantitatif dan $R \& D)$. Bandung: Alfabeta.

Sriraman, Bharath dan English, Lyn. (2010). Theories of Mathematics Education. New York: Spinger Science.

Horison, Suydam; dan Higgins. The Access Center. (2010). Concrete Representational Abstract Instructional Approach. http://www.k8accesscenter.org/training_resources/CRA_Instructional_Approac h.asp.

Thornton, et al. (1983). Teaching Mathematics To Children With Special Needs. Sydney: Addison-Wesley Publishing Company.

Van De Walle, John A. (2002). Matematika Sekolah Dasar dan Menengah Pengembangan Pengajaran Jilid 2. Jakarta: Erlangga.

Van De Welle, John A, Karp, Karen S, dan Bay-Williams, Jennifer M. (2010). Elementary And Middle School Mathematics Teaching Developmentally, $7^{\text {th }}$ Edition. New York: Pearson Education. 